\title{
Unusual ECG pattern of the acute inferior wall infarction due to RCA occlusion with concomitant $L A D$ and $L C X$ disease
}

\author{
Iranna Hirapur, ${ }^{1}$ Rajeshwari Mantgol Veeranna, ${ }^{2}$ Navin Agrawal ${ }^{3}$
}

'Department of Cardiology, R L Jalappa Narayana Hrudyalaya, Kolar, Karnataka, India

${ }^{2}$ Department of Opthalmology, R L Jalappa Narayana Hrudyalaya, Kolar, Karnataka, India

${ }^{3}$ Department of Cardiology, Care Hospital, Surat, Gujarat, India

\section{Correspondence to} Dr Navin Agrawal, drnavinagrawal@gmail.com

Accepted 29 March 2014
To cite: Hirapur I, Veeranna RM, Agrawal N. BMJ Case Rep Published online: [please include Day Month Year] doi:10.1136/ bcr-2014-204492

\section{DESCRIPTION}

Inferior wall myocardial infarction (IWMI) is conventionally described to present with ST segment elevation in leads II, III and aVF. Isolated elevation of the ST segment in one or two leads may be confusing and sometimes non-diagnostic. ${ }^{12}$ The occurrence of such patterns in patients presenting with chest pain may confuse the primary care physicians and may lead to inappropriate delay in management of the infarction.

We report an interesting ECG pattern in a 49-year-old male patient who presented to our institute with acute onset of severe chest pain since $3 \mathrm{~h}$. The patient was a known case of systemic hypertension since the past 5 years and was a chronic smoker. The ECG showed ST segment elevation in lead III, aVF, but there was ST segment depression in lead II and the lateral precordial leads which is very unusual in a case of IWMI (figure 1). The patient was taken up for primary angioplasty. The diagnostic coronary angiogram performed prior to the intervention showed chronic total occlusion of the left anterior descending artery, 90\% stenosis in the left circumflex artery and occlusion of the right coronary artery (RCA) which was the culprit vessel for the infarction (videos 14). After successful primary angioplasty of the culprit RCA lesion, the ST elevation in leads III and aVF, and ST depression in lead II and lateral precordial leads normalised (figure 2). The patient was subsequently discharged with a plan to revascularise the other vessels at a later date in accordance with the symptoms.

This ECG pattern can sometimes be confused with various forms of pseudoinfarct patterns which can be seen in diseases such as hypertrophic and restrictive cardiomyopathies, myocarditis, left ventricular hypertrophy, pneumothorax, conduction blocks and conduction system degeneration, intracranial bleed, hyperkalaemia, Wolff-ParkinsonWhite syndrome acute pancreatitis and pulmonary embolism.

This unusual pattern of ECG is an important variation which needs to be discussed and taken into account for the benefit of the practitioners who deal with such patients. The occurrence of this pattern has not been described in IWMI and neither has it been described in any of the specific diseases listed previously which are known to cause pseudoinfarct patterns, and accurate diagnosis



Figure 1 ECG showing ST segment elevation in leads III and aVF with ST depression in lateral precordial leads. 


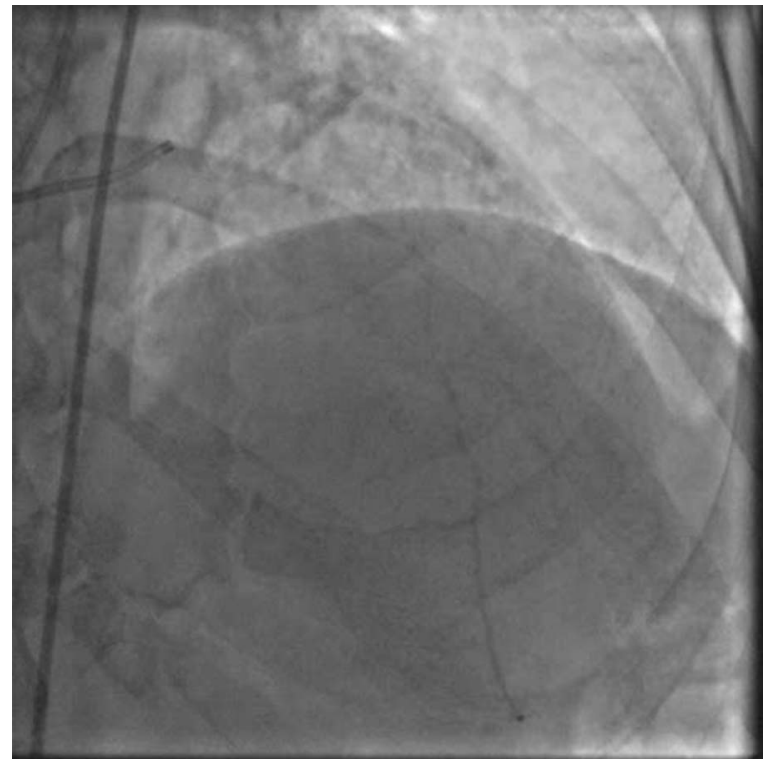

Video 1 RAO cranial view showing chronic occlusion in the mid portion of LAD with retrograde filling of the distal part from homocollaterals.

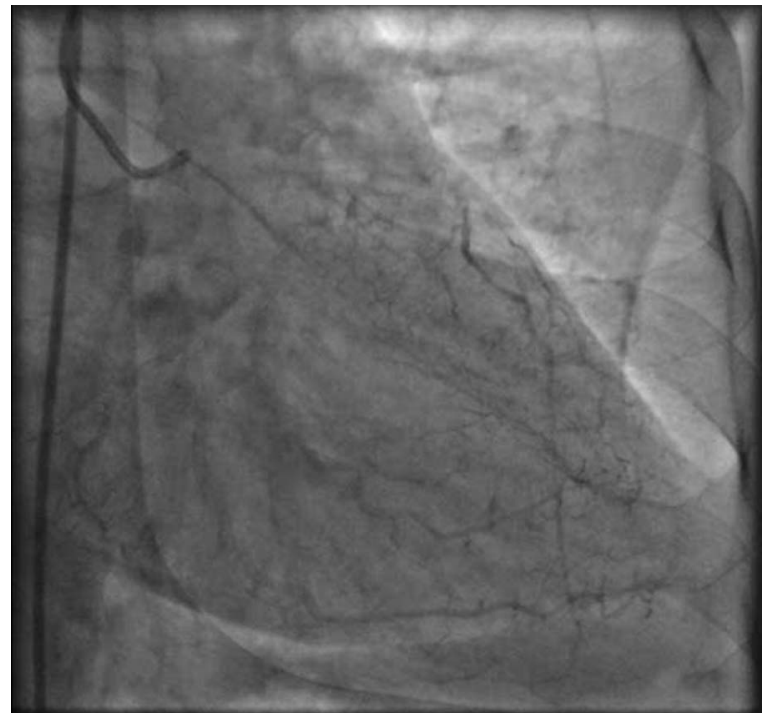

Video 2 RAO caudal view showing critical stenosis of LCX.

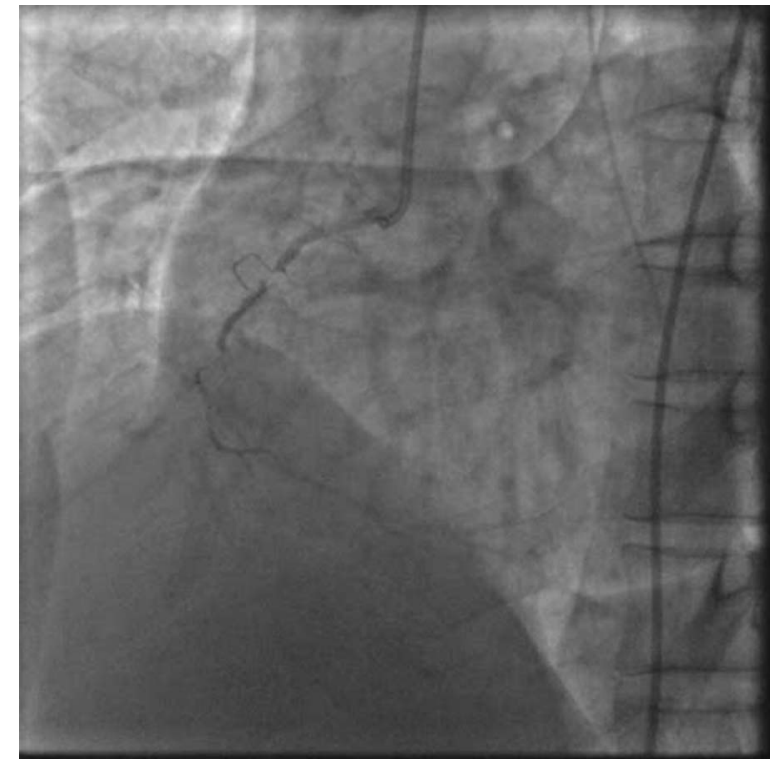

Video 3 LAO view showing occluded infarct related right coronary artery.

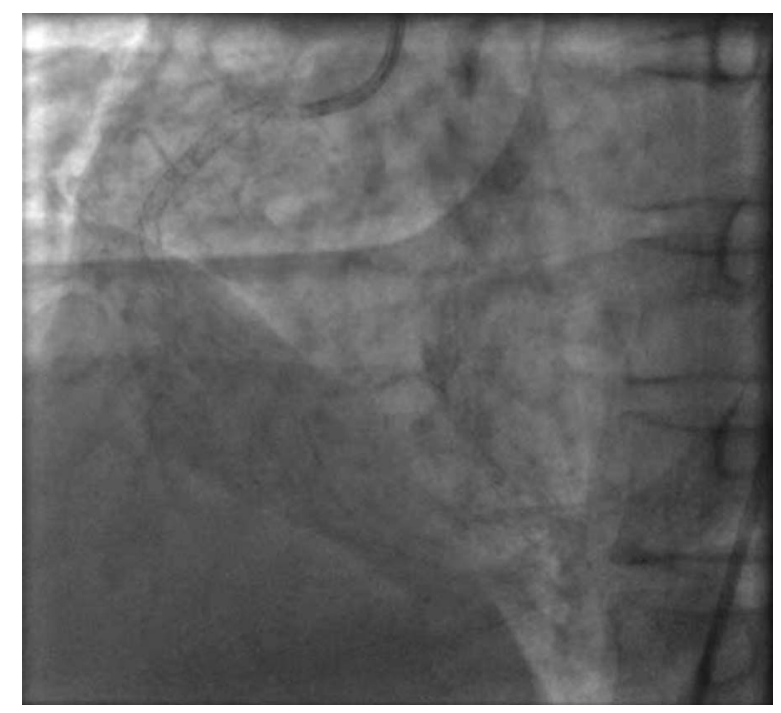

Video 4 LAO view after angioplasty showing patent RCA. 


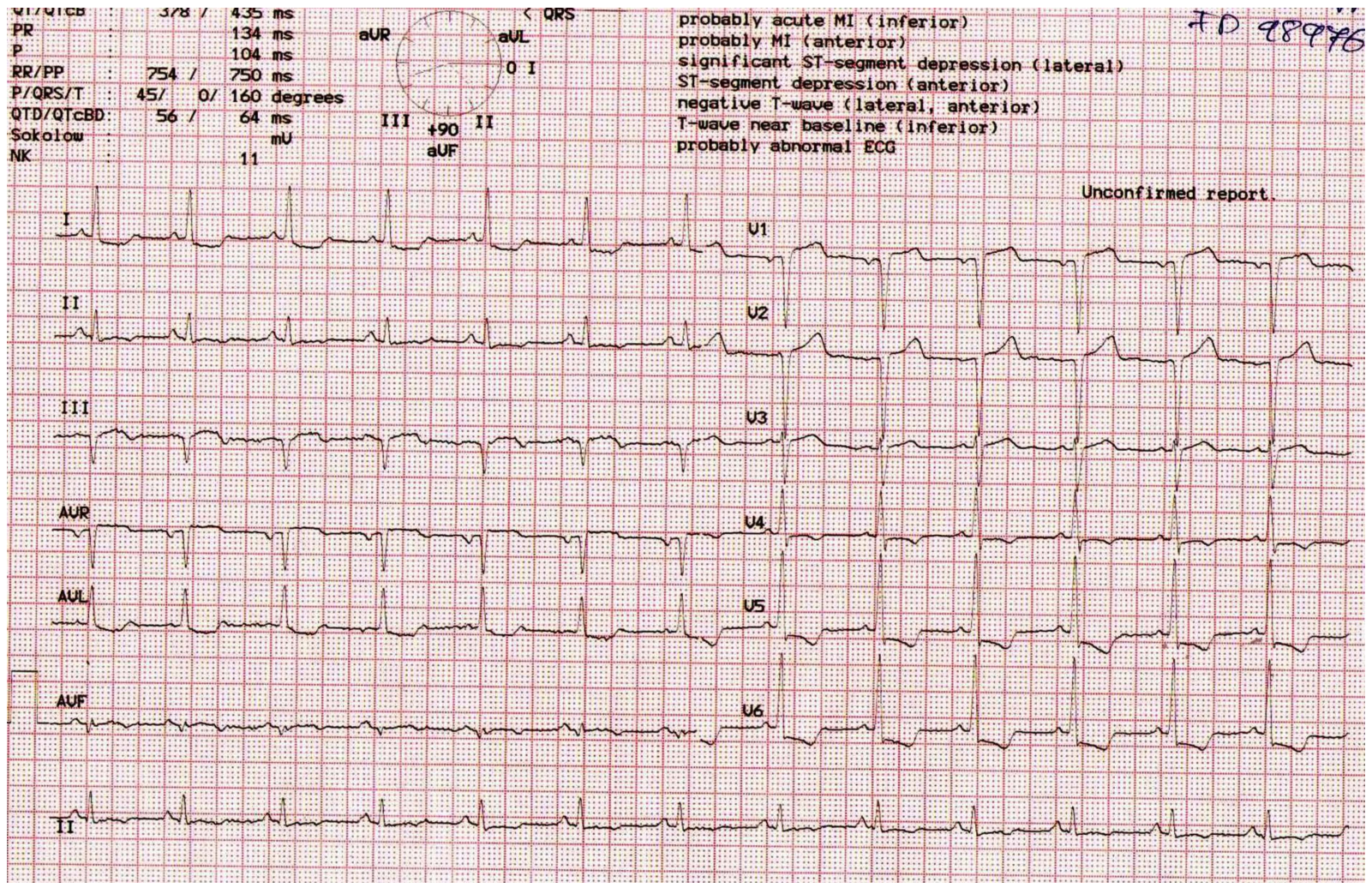

Figure 2 ECG pattern after the angioplasty showing settled ECG changes.

\section{Learning points}

- ST segment depression in inferior leads during an acute ST elevation inferior wall myocardial infarction (IWMI) has never been described before and deserves to be kept in mind for accurate diagnosis and culprit artery localisation which may help in early appropriate management.

- In case of multivessel disease the ST segment vector may be directed abnormally which can lead to unusual ECG patterns which may lead to a diagnostic dilemma.

- This variant of ECG pattern in an IWMI needs to be brought to light and discussed for the understanding of common practitioners to avoid misdiagnosis. should depend on the clinical setting and circumstantial evidence and the use of other diagnostic aids such as echocardiography, cardiac enzymes and angiography is strongly indicated.

\section{Competing interests None.}

Patient consent Obtained.

Provenance and peer review Not commissioned; externally peer reviewed.

\section{REFERENCES}

1 Wung SF, Kahn DY. A quantitative evaluation of ST-segment changes on the 18-lead electrocardiogram during acute coronary occlusions. J Electrocardiol 2006;39:275-81.

2 Menown IB, Mackenzie G, Adgey AA. Optimizing the initial 12-lead electrocardiographic diagnosis of acute myocardial infarction. Eur Heart J 2000;21275-83.

Copyright 2014 BMJ Publishing Group. All rights reserved. For permission to reuse any of this content visit http://group.bmj.com/group/rights-licensing/permissions.

BMJ Case Report Fellows may re-use this article for personal use and teaching without any further permission.

Become a Fellow of BMJ Case Reports today and you can:

- Submit as many cases as you like

- Enjoy fast sympathetic peer review and rapid publication of accepted articles

- Access all the published articles

- Re-use any of the published material for personal use and teaching without further permission

For information on Institutional Fellowships contact consortiasales@bmjgroup.com

Visit casereports.bmj.com for more articles like this and to become a Fellow 